Edusfarm 13 (2021), 73-88

ISSN: 1886-6271

DOI: 10.1344/EDUSFARM2021.13.05

Rebut: 19 de gener de 2021

Acceptat: 26 de febrer de 2021

\title{
ESTUDI DEL MECANISME DE FAGOCITOSI DELS CORPORA AMYLACEA DEL LÍQUID CEFALORRAQUIDI HUMÀ
}

\author{
Bordoy, Maria Milagros; ${ }^{1}$ PElegrí, CARME; \\ VILAPLANA, JORDI; RIBA, MARTA \\ Departament de Bioquímica i Fisiologia \\ Facultat de Farmàcia i Ciències de l'Alimentació \\ Universitat de Barcelona
}

\begin{abstract}
Corpora amylacea (CA) are granular bodies that accumulate in the human brain during aging and neurodegenerative conditions. These structures act as containers that amass waste substances from the brain and they are extruded from the central nervous system to the cerebrospinal fluid (CSF). From the CSF, they reach the cervical lymph nodes, where they can be phagocytosed by macrophages. In this work, human CSF samples and THP-1 derived macrophages were processed by immunofluorescence techniques to study the presence of phagocytosis inducers on the surface of CA, as well as macrophage surface receptors. The results suggest that CA can be phagocytosed by means of the mannose binding lectin, which attaching these bodies would cause a C3b-opsonization. Furthermore, macrophages derived from THP-1 monocytes present C3b receptors that would recognize the C3b that opsonize the CA.
\end{abstract}

Keywords: corpora amylacea, macrophages, phagocytosis, cerebrospinal fluid.

\section{Resumen}

Los corpora amylacea (CA) son unos cuerpos granulares que se acumulan en el cerebro humano durante el envejecimiento y condiciones neurodegenerativas. Estas estructuras actúan como contenedores que capturan sustancias de desecho cerebrales y son extruidos desde el sistema nervioso central hacia el líquido cefalorraquídeo (LCR). Desde el LCR, llegan a los ganglios linfáticos cervicales, donde pueden ser fagocitados por macrófagos. En el presente trabajo, se procesaron muestras de LCR humano y cultivos de macrófagos derivados de monocitos THP-1 mediante técnicas de inmunofluorescencia para estudiar la presencia de inductores de fagocitosis en la superficie de los CA, así como los receptores correspondientes en la superficie de los macrófagos. Los resultados sugieren que los CA pueden ser fagocitados mediante la lectina de unión a la manosa, que al unirse a los CA provocaría la opsonización de estos con C3b. Por otro lado, los macrófagos de estudio presentan receptores de C3b, que reconocerían el C3b que opsoniza los CA.

Palabras clave: corpora amylacea, macrófagos, fagocitosis, líquido cefalorraquídeo.

\section{Resum}

Els corpora amylacea $(\mathrm{CA})$ són uns cossos granulars que s'acumulen al cervell humà durant l'envelliment i condicions neurodegeneratives. Aquestes estructures actuen com a contenidors que capturen substàncies de rebuig cerebrals i són extruïts des del sistema nerviós central cap al líquid cefalorraquidi (LCR). Des del LCR, arriben als

\footnotetext{
${ }^{1}$ Farmacèutica exercent en oficina de farmàcia. Graduada en Farmàcia. Col·laboradora del grup de la Barrera Hematoencefàlica del Departament de Bioquímica i Fisiologia de la Facultat de Farmàcia i Ciències de l'Alimentació de la Universitat de Barcelona (mariabordoy@outlook.es).
} 
ganglis limfàtics cervicals, on poden ser fagocitats per macròfags. En aquest treball es van processar mostres de LCR humà i cultius de macròfags derivats de monòcits THP-1 mitjançant tècniques d'immunofluorescència per estudiar la presència d'inductors de fagocitosi a la superfície dels CA, així com els receptors corresponents a la superfície dels macròfags. Els resultats suggereixen que els CA poden ser fagocitats mitjançant la lectina d'unió a la mannosa, que en unir-se als CA provocaria la seva opsonització amb C3b. Per altra banda, els macròfags d'estudi presenten receptors de C3b, que reconeixerien el C3b que opsonitza els CA.

Paraules clau: corpora amylacea, macròfags, fagocitosi, líquid cefalorraquídi

\section{Introducció}

L'envelliment és un procés biològic natural que es caracteritza per la pèrdua progressiva de la integritat fisiològica, que dona lloc a diverses alteracions funcionals i a l'augment de la vulnerabilitat a la mort. Aquest deteriorament s'ha descrit com a factor de risc per a les principals patologies humanes, com el càncer, els trastorns cardiovasculars i les malalties neurodegeneratives (López-Otín et al., 2013, pp. 1194-1217).

El cervell dels mamífers i, per tant, també l'humà, d'acord amb el seu elevat metabolisme i consum d'oxigen, presenta alteracions addicionals durant la senescència respecte als altres òrgans. Aquests mecanismes donen lloc a un increment en la producció d'espècies reactives d'oxigen, de les quals deriva un augment de l'estrès oxidatiu, que causa una pèrdua progressiva de l'estructura i la funció de les neurones i, en conseqüència, un declivi de les funcions del cervell tals com la memòria i l'aprenentatge, així com de les funcions motores i sensitives, fet que caracteritza les malalties neurodegeneratives. Actualment s'utilitzen diversos tractaments per pal-liar la simptomatologia associada a aquests processos neurodegeneratius, però no existeix cap teràpia definitiva per aturar la seva progressió (Koivisto et al., 1995, pp. 741-747; Comas-Herrera et al., 2007, pp. 1037-1045; Sibille, 2013, pp. 53-65).

Lligades a l'envelliment cerebral en humans es troben unes estructures anomenades corpora amylacea (CA), les quals van ser descrites per primera vegada per J. E. Purkinje en un congrés a Praga l'any 1837 (Purkinje, 1839, pp. 177-180). Els CA es troben presents al cervell de persones d'edat avançada, però fins fa poques dècades no es va considerar que tinguessin cap rellevància clínica. Aquestes estructures incrementen en nombre durant l'envelliment en cervells humans sans, però també ho fan en diferents zones del cervell en diverses malalties neurodegeneratives com l'Alzheimer, el Parkinson, les malalties de Huntington i Pick, així com en pacients amb epilèpsia del lòbul temporal, entre d'altres (Cavanagh, 1999, pp. 265-295; Pirici i Margaritescu, 2014, pp. 33-57).

Pel que fa a la seva morfologia, cal destacar que són estructures esfèriques i que la seva mida pot variar segons la seva localització. Poden mesurar entre 2 i $20 \mu \mathrm{m}$ de diàmetre, tot i que en alguns casos poden arribar a $50 \mu \mathrm{m}$. Al còrtex, a l'estriat i a la matèria grisa de la medul·la espinal, els CA són més petits que en d'altres zones. Com s'ha comentat anteriorment, en general són cossos esfèrics, tot i que s'han descrit també formes ovalades i elongades. La seva superfície acostuma a ser llisa, però no és infreqüent trobar CA que presentin una superfície irregular, com si tinguessin una coberta (Cavanagh, 1999, pp. 265-295).

La distribució cerebral dels CA és àmplia. De fet, se'n poden trobar a gairebé totes les regions del sistema nerviós central, però tendeixen a acumular-se en determinades localitzacions. En el cervell, es troben congregats principalment en el recobriment glial que es troba sota el revestiment de les cèllules ependimàries dels ventricles, particularment sota el cos callós i el sostre del tercer i quart ventricle. A les superfícies més externes del cervell, es troben generalment en el recobriment glial sota la piamàter, especialment a la base del cervell, en les superfícies medials dels lòbuls temporals i sobre les formacions de l'hipocamp. S'ha descrit també que els CA s'acumulen a les zones perivasculars del cervell humà (Cavanagh, 1999, pp. 265-295; Sakai et al., 1969, pp. 526-544). Cal destacar que aquestes localitzacions són properes al líquid cefalorraquidi (LCR) (figura 1), motiu que ha donat pas 
Edusfarm 13 (2021), 73-88

ISSN: $1886-6271$

al fet que diferents autors hagin suggerit al llarg dels anys que els CA són expulsats cap a l'LCR. L'estudi de Sbarbati et al. (1996, pp. 196-201) suggereix un possible mecanisme d'extrusió dels CA cap a fora del cervell.

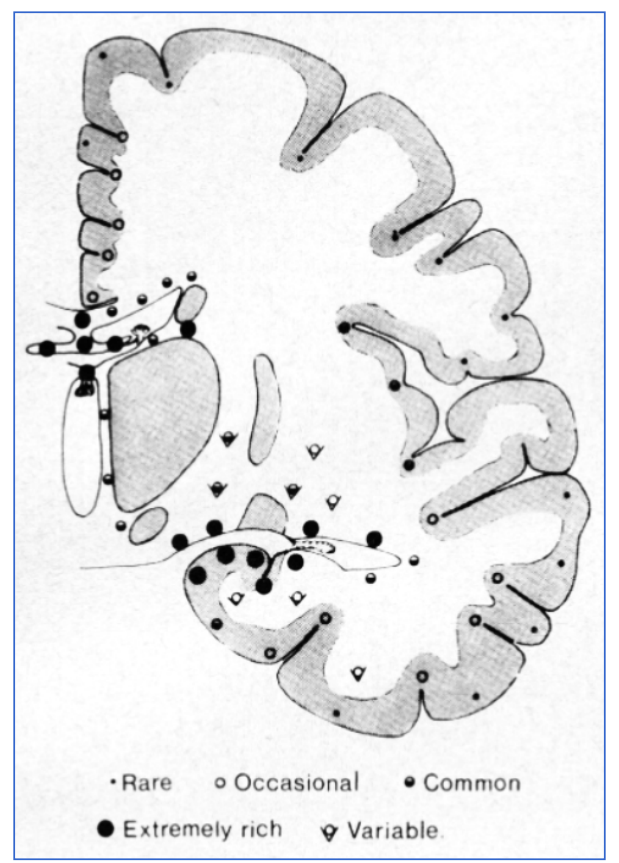

Figura 1. Esquema referent a la distribució dels CA en el cervell humà. Els CA tendeixen a concentrar-se en zones properes a l'LCR (Sakai et al., 1969, p. 533).

En referència a la seva composició, diferents reaccions histoquímiques indiquen que els CA estan essencialment formats per polímers de glucosa: donen un marcatge positiu a la tinció de l'àcid periòdic de Schiff (PAS) (figura $2 a$ ) i, a més a més, la digestió prèvia del teixit amb $\alpha$-amilasa redueix la tinció de PAS. Complementàriament, l'anàlisi bioquímica d'aquestes estructures ha permès determinar que els CA tenen una composició del $88 \%$ de polímers de glucosa, $5 \%$ de proteïnes i $3 \%$ de fosfats (Cavanagh, 1999, pp. 265-295; Sakai et al., 1969, pp. 526-544).

S'ha observat que durant la formació dels CA apareixen uns neoepítops (NEs) que no estan presents en estructures sanes, i s'ha posat de manifest que aquests poden ser reconeguts per immunoglobulines M (IgMs) naturals (Augé et al., 2017, p. 41807) (figura 2b). Aquests anticossos es generen de manera espontània ja des dels estadis fetals, sense contacte previ amb antígens externs (Coutinho, Kazatchine i Avrameas, 1995, pp. 812-818). Les IgMs participen en l'homeòstasi dels teixits i la regulació de cèllules i enzims, i també reconeixen estructures glicosilades o oxidades que resulten de l'estrès oxidatiu, un fenomen que es troba incrementat en l'envelliment (Goldin et al., 2006, pp. 597605; Lutz, Binder i Kaceri, 2009, pp. 43-51).

S'ha observat que l'accés de les IgMs naturals al parènquima cerebral queda restringit per la barrera hematoencefàlica (BHE) en condicions fisiològiques. Això fa que la unió entre les IgMs i els NEs dels CA només es pugui produir quan la BHE es veu alterada, permetent així el pas de les IgMs, o bé quan els CA són extruïts fora del cervell (Augé et al., 2017, p. 41807). 

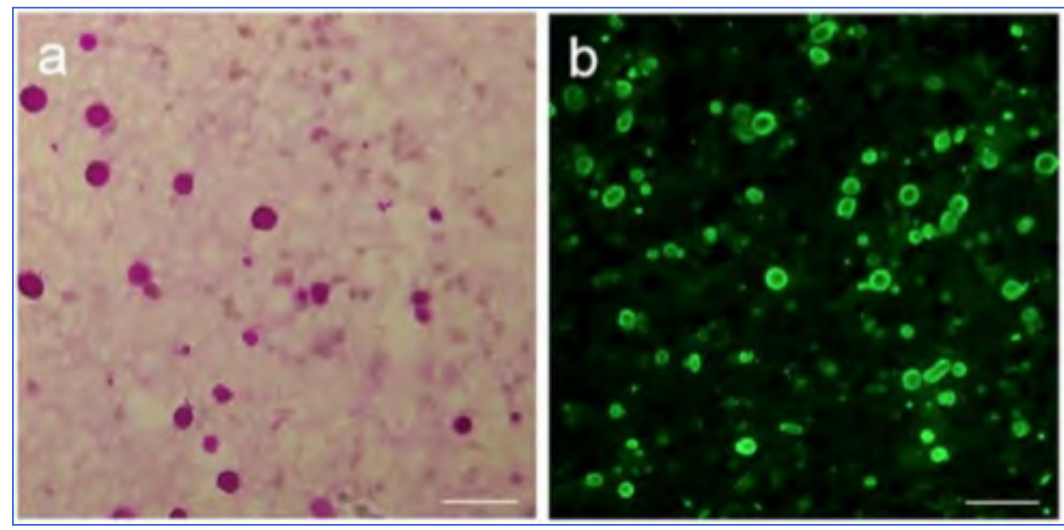

Figura 2. a) Imatge representativa de la tinció de PAS que illlustra la presència de CA en una secció d'hipocamp d'un donant d'AD. $b$ ) Imatge representativa d'immunofluorescència que il-lustra la presència de CA marcats amb IgM (verd) en una secció cerebral d'un donant d'AD (Augé et al., 2017, p. 41807). Barra d'escala: $50 \mu \mathrm{m}$.

Estudis posteriors han posat de manifest que les IgMs dirigides contra els NEs dels CA es troben sovint com a contaminants en els vials d'anticossos comercials utilitzats en els estudis d'immunohistoquímica. La presència d'aquests anticossos provoca falsos marcatges dels $\mathrm{CA}$, i aquests falsos marcatges han fet que molts dels components descrits en els CA i moltes de les teories publicades siguin errònies o inconsistents (Augé et al., 2017, p. 41807; Augé et al., 2018, p. 13525).

Actualment, hi ha consens que els CA estan constituïts per polímers de glucosa. S'ha proposat que també contenen glicogen sintasa, que formaria els polímers, així com elements residuals o productes de degradació i molècules que intervenen en la senyalització i degradació de substrats, com la ubiqüitina i la p62 (Augé et al., 2017, p. 41807; Augé et al., 2018, p. 13525).

Recentment, s'ha confirmat que els CA són extruïts del cervell cap a l'LCR i, posteriorment, accedeixen als ganglis limfàtics cervicals probablement a través del sistema limfàtic meningi (Riba et al., 2019, pp. 26038-26048). D'acord amb tot això, es postula que aquests cossos poden estar involucrats en la captura i el segrest de productes potencialment perillosos i substàncies de rebuig.

$S^{\prime}$ ha comprovat també que algunes cèllules ganglionars estableixen contacte amb els CA i es pensa que aquestes podrien ser macròfags. De fet, la fagocitosi dels CA per part de macròfags ha estat demostrada mitjançant tècniques de cultiu in vitro (figura 3 ), utilitzant macròfags derivats de monòcits THP-1 (THP-1') i CA procedents de l'LCR. Es desconeix, però, el mecanisme pel qual aquesta fagocitosi es porta a terme (Riba et al., 2019, pp. 26038-26048). 


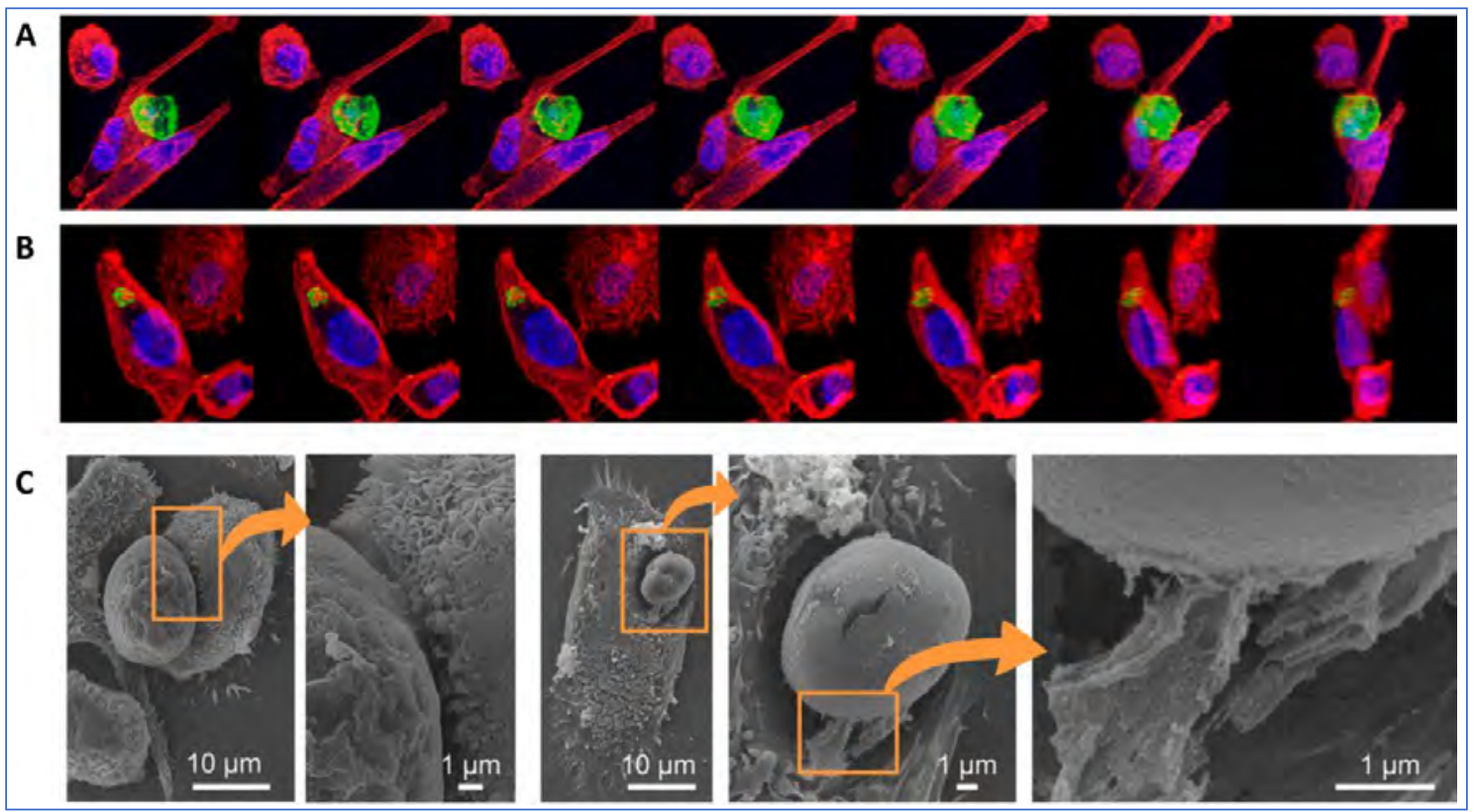

Figura 3. $A$ i $B$ ) Seqüències d'imatges que mostren un macròfag fagocitant un CA opsonitzat amb IgMh des de diferents punts de vista. Les seqüències es van realitzar després d'una reconstrucció en 3D a partir d'imatges obtingudes per microscòpia confocal. Els macròfags estan tenyits amb falloïdina (vermell) i els seus nuclis, marcats amb reactiu de Hoechst (blau). Els CA estan marcats amb $\alpha$-IgM (verd). $C$ ) Imatges de microscòpia electrònica de rastreig que mostren també un macròfag engolint un CA opsonitzat amb IgMh. Es van observar alguns fil·lopodis emergint dels macròfags i entrant en contacte amb els CA (Riba et al., 2019, pp. 26038-26048).

A la figura 4 es resumeix el procés que seguirien els CA, des de la seva formació als astròcits fins a la seva degradació als ganglis limfàtics cervicals gràcies a l'activitat dels macròfags. 


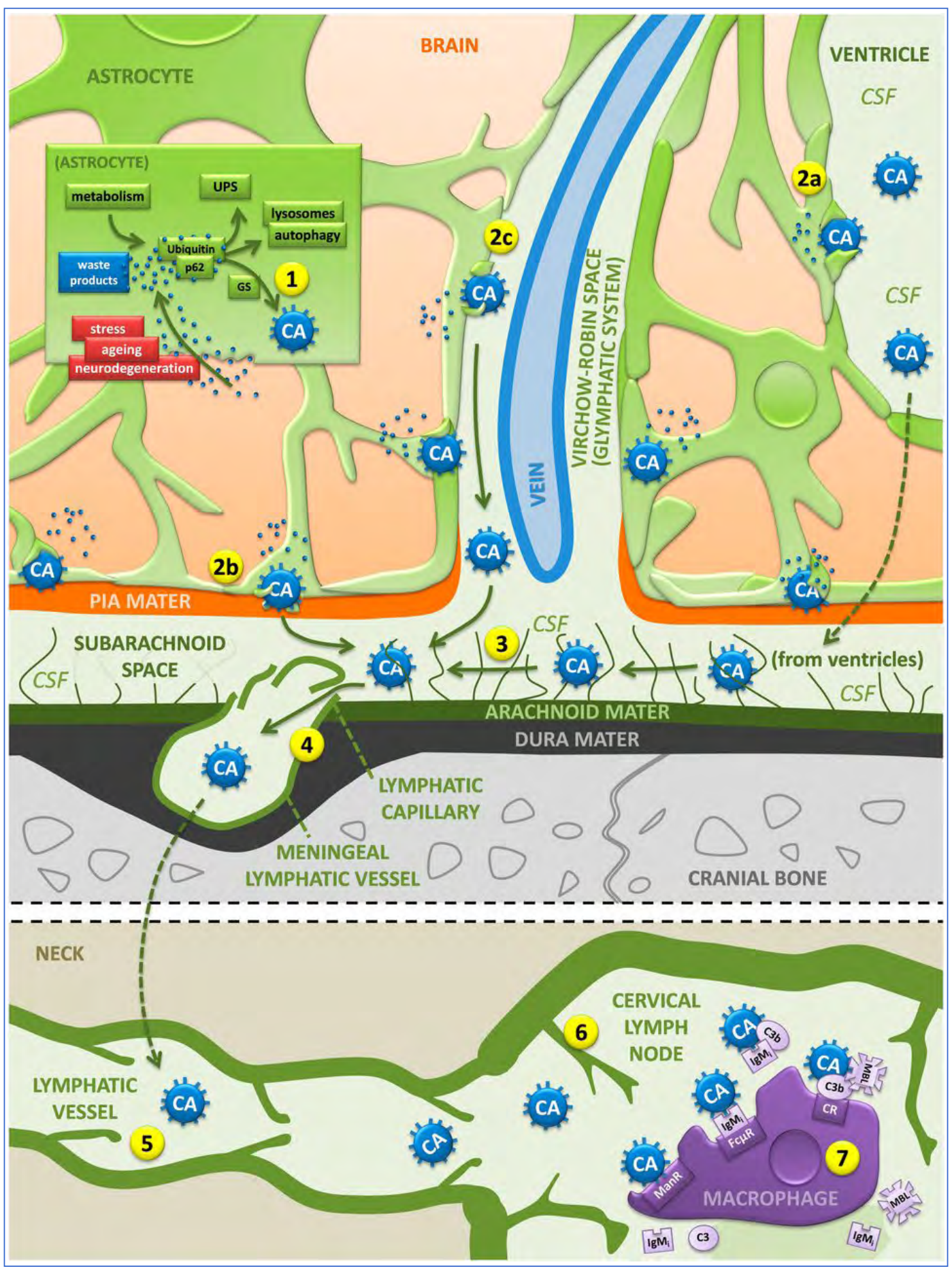

Figura 4. Representació del recorregut que realitzarien els CA des de les digitacions astrocítiques al cervell, passant per l'LCR i arribant als ganglis limfàtics cervicals, on serien degradats per macròfags, participant així en l'eliminació de substàncies de rebuig (Riba et al., 2019, pp. 26038-26048). C3: component C3 del sistema del complement; C3b: fragment C3b del sistema del complement provinent de l'escissió de C3; CR: receptor del fragment C3b del sistema del complement; CA: corpora amylacea; CSF: cerebrospinal fluid (líquid cefalorraquidi); Fc $\mu$ R: receptor del fragment Fc de les IgMs; ManR: receptor de mannosa; MBL: mannose binding lectin (lectina d'unió a la mannosa); UPS: ubiquitin-proteasome system (sistema de proteosoma d'ubiqüitina). 
Edusfarm 13 (2021), 73-88

ISSN: $1886-6271$

Tal com s'ha comentat anteriorment, els CA contenen NEs que són reconeguts per IgMs naturals, les quals podrien contribuir a la fagocitosi d'aquests cossos, bé sigui perquè aquestes són reconegudes pel receptor específic de les IgMs (Fc $\mu$ R o FAIM3) expressat en la superfície de fagòcits o bé perquè, unides als NEs dels CA podrien activar el sistema del complement per la via clàssica provocant l'opsonització dels CA amb C3b. Aquest fragment de proteïna podria ser reconegut pel C3bR que estaria present a la superfície dels macròfags.

Convé ressaltar que els CA són reconeguts també per la concanavalina A (ConA) (Cavanagh, 1999, pp. 265-295), una lectina d'origen vegetal que reconeix determinades hexoses, entre les quals destaca la mannosa (Varki et al., 2017). Aquesta hexosa podria ser reconeguda pel receptor de la mannosa (ManR o CD206) present a la membrana plasmàtica de macròfags i activar el procés de fagocitosi.

Addicionalment, la mannosa també pot ser reconeguda per la mannose binding lectin (MBL) humana com a activadora de la via de la lectina del sistema del complement (Barnum, 1995, pp. 132-146).

L'activació del sistema del complement, tant mitjançada per anticossos (via clàssica) com per MBL (via de la lectina), convergeix en l'escissió de la proteïna C3 en els fragments C3a i C3b, i aquest últim podria opsonitzar els CA. A més a més, el C3b pot ser resultat d'una escissió espontània de C3 coneguda com la via alternativa (Sarma i Ward, 2011, pp. 227-235).

Tots aquests mecanismes podrien desencadenar la fagocitosi dels CA per part dels macròfags, tal com es resumeix a la figura 5 .

Considerant que l'LCR no conté IgMs en condicions fisiològiques, però que sí que conté MBL i diverses proteïnes del sistema del complement (Barnum, 1995, pp. 132-146; Lanzrein, Jobst i Sim, 1998, pp. 1491-1495), l'activació del sistema del complement i l'opsonització dels CA amb C3b es podrien produir ja a l'LCR. Així doncs, és interessant estudiar si aquests components intervenen en la fagocitosi dels CA per part de THP-1'.

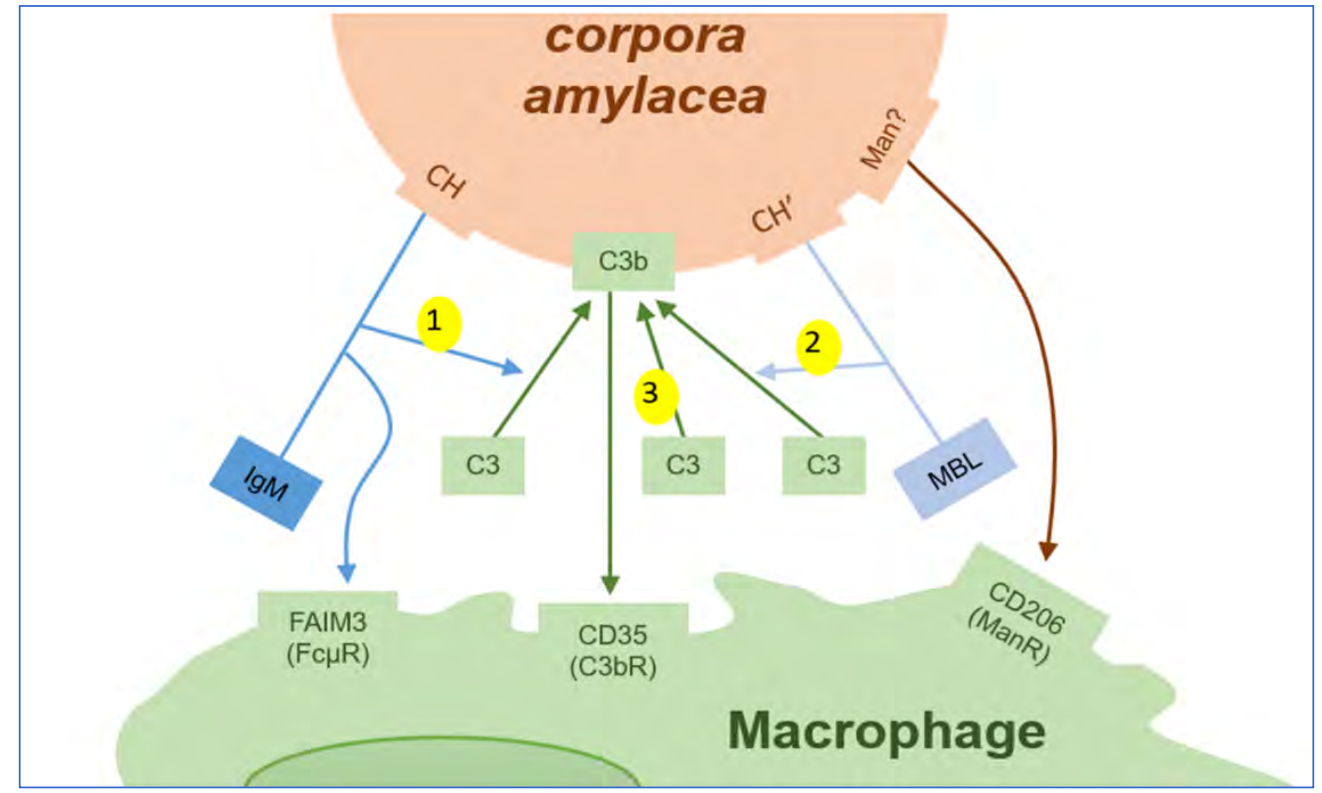

Figura 5. Esquema representatiu de les possibles vies de fagocitosi dels CA per part dels macròfags. Veure l'explicació detallada al text. CA: corpora amylacea, $\mathrm{CH}$ : Carbohidrat, IgM: immunoglobulina M, FAIM3 o Fc $\mu$ R: receptor de IgMs en macròfags, C3: component C3 del sistema del complement, C3b: fragment C3b generat des de C3, CD35 o C3bR: receptor de C3b en macròfags, Man: mannosa, MBL: mannose binding lectin, CD206 o ManR: receptor de mannosa en macròfags. 1: via clàssica, 2: via de la lectina, 3: via alternativa. 


\section{Material i mètodes}

\subsection{Obtenció de mostres de sediment d'LCR}

Les mostres de sediment d'LCR utilitzades en aquest estudi, proporcionades pel Banc de Teixits Neurològics (Biobanc de l'Hospital Clínic-IDIBAPS de Barcelona) van procedir de 7 casos de malalties neurodegeneratives (taula 1 ).

Les mostres d'LCR van ser extretes post mortem de líquid ventricular i, immediatament després de l'extracció, el Banc de Teixits Neurològics va aplicar un protocol de neteja de les mostres que es basa en una centrifugació de l'LCR a $4000 \mathrm{~g}$ i $4{ }^{\circ} \mathrm{C}$ durant 10 minuts. Considerant que els CA ja precipiten a $650 \mathrm{~g}$ (Sakai et al., 1969, pp. 526-544), aquests es troben al sediment obtingut d'aquesta centrifugació. Per tant, és el sediment el que es va utilitzar en el present estudi.

Els sediments d'LCR es van mantenir a $-80^{\circ} \mathrm{C}$ des de la seva obtenció fins a arribar al laboratori, on es van descongelar i es van resuspendre en un volum de phosphate buffered saline (PBS, pH $=7,2$ ) corresponent al volum inicial d'LCR abans de la centrifugació a $4000 \mathrm{~g}$, i se'n van generar alíquotes de $500 \mu \mathrm{L}$. Aquestes alíquotes van ser conservades a $-80^{\circ} \mathrm{C}$ fins a la seva manipulació.

Els experiments es van realitzar d'acord amb l'aprovació del Comitè Ètic de la Universitat de Barcelona.

TAULA 1. EDAT, SEXE, DIAGNÒSTIC CLÍNIC I HORES DE RETARD

DESPRÉS DE LA MORT (POST MORTEM DELAY, PMD) EN HORES: MINUTS DELS DIFERENTS CASOS UTILITZATS PER A L'ESTUDI DE L'LCR.

\begin{tabular}{|c|c|c|c|c|}
\hline CAS & EDAT & SEXE & PMD & DIAGNÒSTIC CLÍNIC \\
\hline $\mathbf{1}$ & 71 & Home & $12: 00$ & Demència no filiada \\
\hline $\mathbf{2}$ & 69 & Dona & $07: 08$ & Esclerosi lateral amiotròfica \\
\hline $\mathbf{3}$ & 68 & Dona & $10: 20$ & Alzheimer presenil \\
\hline $\mathbf{4}$ & 64 & Home & $09: 48$ & Alzheimer presenil \\
\hline $\mathbf{5}$ & 69 & Home & $09: 15$ & Parkinsonisme \\
\hline $\mathbf{6}$ & 69 & Dona & $13: 15$ & Alzheimer presenil \\
\hline $\mathbf{7}$ & 83 & Home & $14: 45$ & Paràlisi supreanuclear progressiva \\
\hline
\end{tabular}

\subsection{Marcatge de CA d'LCR amb ConA}

Es van deixar descongelar alíquotes de $500 \mu \mathrm{L}$ de sediment d'LCR resuspès amb PBS de cada un dels diferents casos. Seguidament, es van realitzar 6 centrifugacions a $700 \mathrm{~g}$ durant 10 minuts, descartant el sobrenedant després de cada una d'elles i resuspenent el sediment amb $500 \mu \mathrm{L}$ de PBS a excepció de la darrera centrifugació, la sisena, en la qual el sediment es va resuspendre amb $300 \mu \mathrm{L}$ d'una dilució de ConA marcada amb fluoresceïna, en PBS (taula 2). Les mostres es van deixar 21 hores en agitació a $4{ }^{\circ} \mathrm{C}$ i protegides de la llum. 
Edusfarm 13 (2021), 73-88

ISSN: $1886-6271$

TAULA 2. CARACTERÍSTIQUES DEL MARCADOR EMPRAT EN L'EXPERIMENT. ES CONCRETA LA DILUCIÓ UTILITZADA, EL FLUOROCROM I LA CASA COMERCIAL.

\begin{tabular}{|c|c|c|c|}
\hline MARCADOR & DILUCIÓ & FLUOROCROM & CASA COMERCIAL \\
\hline ConA & $1 / 250$ & Fluorescein & Vector Laboratories, Burlingame, EUA \\
\hline
\end{tabular}

Posteriorment, es va realitzar una centrifugació més a $700 \mathrm{~g}$ durant 10 minuts, es va descartar el sobrenedant, es va resuspendre amb $1000 \mu \mathrm{L}$ de PBS i es va deixar 10 minuts en agitació a la foscor. A continuació es va fer una última centrifugació a $700 \mathrm{~g}$ durant 10 minuts, es van descartar els sobrenedants i es van resuspendre amb $40 \mu \mathrm{L}$ de PBS.

Es van posar els $40 \mu \mathrm{L}$ de cada una de les mostres en diferents portaobjectes i es van deixar assecar a temperatura ambient protegides de la llum.

Es va procedir a dibuixar un pou amb el retolador hidròfob als portaobjectes, es van muntar les preparacions utilitzant $120 \mu \mathrm{L}$ de Fluoromount (Electron Microscopy Sciences, PA, EUA) i es van deixar assecar a temperatura ambient, en un ambient sec i tancat i protegides de la llum.

\subsection{Marcatge d'MBL dels CA d'LCR}

Es van deixar descongelar alíquotes de $500 \mu \mathrm{L}$ de sediment d'LCR resuspès amb PBS de cada un dels diferents casos. Seguidament, es van realitzar 6 centrifugacions a $700 \mathrm{~g}$ durant 10 minuts, descartant el sobrenedant després de cada una d'elles i resuspenent el sediment amb $500 \mu \mathrm{L}$ de PBS, a excepció de la darrera centrifugació, la sisena, en la qual el sediment es va resuspendre amb $300 \mu \mathrm{L}$ d'anticòs primari $\alpha$ MBL-FITC diluït en PBS (taula 3).

Les mostres es van deixar 21 hores en agitació a $4{ }^{\circ} \mathrm{C}$ i protegides de la llum.

TAULA 3. CARACTERÍSTIQUES DE L'ANTICÒS EMPRAT EN L'EXPERIMENT. ES CONCRETA L'HOSTE, SI HA ESTAT PURIFICAT, LA DILUCIÓ UTILITZADA, EL FLUOROCROM I LA CASA COMERCIAL.

\begin{tabular}{|c|c|c|c|c|c|}
\hline ANTICÒS & HOSTE & PURIFICACIÓ & DILUCIÓ & FLUOROCROM & CASA COMERCIAL \\
\hline $\boldsymbol{\alpha M B L}$ & Conill & Sí & $1 / 100$ & FITC & $\begin{array}{c}\text { Biorbyt, Cambridge, } \\
\text { Regne Unit }\end{array}$ \\
\hline
\end{tabular}

Posteriorment, es va realitzar una centrifugació a $700 \mathrm{~g}$ durant 10 minuts, es van descartar els sobrenedants, es van resuspendre els sediments amb $1000 \mu \mathrm{L}$ de PBS i es van deixar les mostres 10 minuts en agitació i protegides de la llum. Es va tornar a realitzar una centrifugació a $700 \mathrm{~g}$ durant 10 minuts, es van descartar els sobrenedants i es van resuspendre amb $40 \mu \mathrm{L}$ de PBS.

Es van posar els $40 \mu \mathrm{L}$ de cada una de les mostres en diferents portaobjectes i es van deixar assecar a temperatura ambient protegides de la llum.

Es va procedir a dibuixar els pous amb el retolador hidròfob als portaobjectes, es van muntar les preparacions utilitzant $120 \mu \mathrm{L}$ de Fluoromount (Electron Microscopy Sciences) i es van deixar assecar a temperatura ambient i a la foscor en un ambient sec i tancat.

\subsection{Marcatge de C3b dels CA d'LCR}

Es van deixar descongelar alíquotes de $500 \mu \mathrm{L}$ de sediment de LCR resuspès amb PBS de cada un dels diferents casos. Seguidament, es van realitzar 6 centrifugacions a $700 \mathrm{~g}$ durant 10 minuts, descartant el sobrenedant després de cada una d'elles i resuspenent el sediment amb $500 \mu \mathrm{L}$ de PBS, a excepció 
de la darrera centrifugació, la sisena, en la qual el sediment es va resuspendre amb $300 \mu \mathrm{L}$ d'anticòs primari $\alpha$ C3b diluït en PBS (taula 4).

Per tal d'obtenir controls negatius, es va incubar una mostra de sediment de cada un dels casos amb PBS en comptes de l'anticòs primari.

Les mostres es van deixar 21 hores en agitació a $4{ }^{\circ} \mathrm{C}$.

A continuació, es va realitzar una centrifugació a $700 \mathrm{~g}$ durant 10 minuts, es van descartar els sobrenedants, es van resuspendre les mostres amb $1000 \mu \mathrm{L}$ de PBS i es van deixar 10 minuts en agitació. Es va tornar a realitzar una centrifugació a $700 \mathrm{~g}$ durant 10 minuts, es van descartar els sobrenedants de totes les mostres i es van resuspendre amb $300 \mu \mathrm{L}$ d'anticòs secundari $\alpha$ IgG2b de ratolí diluït en PBS (taula 4).

TAULA 4. CARACTERÍSTIQUES DE L'ANTICÒS PRIMARI I L'ANTICÒS SECUNDARI EMPRATS EN L'EXPERIMENT. ES CONCRETA L'HOSTE, SI HA ESTAT PURIFICAT, LA DILUCIÓ UTILITZADA, EL FLUOROCROM I LA CASA COMERCIAL.

\begin{tabular}{|c|c|c|c|c|c|}
\hline ANTICÒS & HOSTE & PURIFICACIÓ & DILUCIÓ & FLUOROCROM & CASA COMERCIAL \\
\hline $\begin{array}{c}\mathbf{\alpha C 3 b} \\
\mathbf{\alpha}_{\mathbf{\alpha I g}} \mathbf{2 b}\end{array}$ & Ratolí & Sí & $1 / 100$ & - & $\begin{array}{c}\text { Abcam, Cambridge, } \\
\text { Regne Unit }\end{array}$ \\
\hline $\begin{array}{c}\mathbf{\alpha I g G}_{\mathbf{2 b}} \mathbf{d e} \\
\text { ratolí }\end{array}$ & Cabra & Sí & $1 / 250$ & $\begin{array}{c}\text { Alexa Fluor 555 } \\
\text { (AF555) }\end{array}$ & $\begin{array}{c}\text { Life Technologies, } \\
\text { Eugene, EUA }\end{array}$ \\
\hline
\end{tabular}

Es van deixar les mostres en agitació durant 1 hora protegides de la llum i a temperatura ambient.

Seguidament, es va realitzar una centrifugació a $700 \mathrm{~g}$ durant 10 minuts, es van descartar els sobrenedants, es van resuspendre amb $500 \mu \mathrm{L}$ de PBS i es van deixar en agitació durant 10 minuts protegides de la llum. Es va fer una última centrifugació a $700 \mathrm{~g}$ durant 10 minuts, es van descartar els sobrenedants i es van resuspendre amb $40 \mu \mathrm{L}$ de PBS.

Es van posar els $40 \mu \mathrm{L}$ de cada una de les mostres en diferents portaobjectes i es van deixar assecar a temperatura ambient protegides de la llum.

Es va procedir a dibuixar un pou amb el retolador hidròfob als portaobjectes, es van muntar les preparacions utilitzant $120 \mu \mathrm{L}$ de Fluoromount (Electron Microscopy Sciences) i es van deixar assecar a temperatura ambient $i$ a la foscor en un ambient sec i tancat.

\subsection{Marcatge de C3b dels CA d'LCR}

Es van utilitzar THP-1', els quals es van obtenir seguint el protocol descrit per Martin et al. (2017). Els macròfags es van cultivar i diferenciar sobre cobreobjectes rodons introduïts en els pous de plaques amb 24 pous.

Per procedir amb l'estudi d'immunofluorescència, en ambdós casos, es va fixar la mostra amb paraformaldehid al $4 \%$ durant 15 minuts i es va rentar amb PBS dues vegades durant 5 minuts. Es va procedir al bloqueig i la permeabilització de la mostra amb una solució preparada amb Tritó-X-100 (Sigma-Aldrich, Darmstadt, Alemanya) al 0,1 \% en tampó de bloqueig (blocking buffer, BB: 1 \% d'albúmina sèrica bovina - Sigma-Aldrich - en PBS) durant 20 minuts a temperatura ambient.

Després de rentar-les dues vegades amb PBS, durant 5 minuts cada rentat, es van incubar les mostres amb l'anticòs primari diluït en BB durant 21 hores a $4{ }^{\circ} \mathrm{C}$ (taula 5). 
Edusfarm 13 (2021), 73-88

ISSN: $1886-6271$

TAULA 5. CARACTERÍSTIQUES DELS ANTICOSSOS PRIMARIS EMPRATS

EN L'EXPERIMENT. ES CONCRETA L'HOSTE, SI HA ESTAT PURIFICAT,

LA DILUCIÓ UTILITZADA, EL FLUOROCROM I LA CASA COMERCIAL.

\begin{tabular}{|c|c|c|c|c|c|}
\hline ANTICÒS & ISOTIP & HOSTE & PURIFICACIÓ & DILUCIÓ & CASA COMERCIAL \\
\hline $\boldsymbol{\alpha M a n R}$ & IgG & Conill & Sí & $1 / 600$ & Abcam \\
\hline $\mathbf{\alpha C 3 b R}$ & $\operatorname{IgG}_{1}$ & Ratolí & Sí & $1 / 40$ & $\begin{array}{c}\text { Thermo Fisher Scientific, } \\
\text { Rockfort, EUA }\end{array}$ \\
\hline
\end{tabular}

Es van rentar amb PBS dues vegades, durant 5 minuts cada rentat, i, posteriorment, es van incubar amb l'anticòs secundari diluït en BB (taula 6). Per protegir el marcatge de la llum, es va cobrir la placa amb paper d'alumini. L'anticòs secundari es va deixar incubar durant una hora, i en els últims 5 minuts es va afegir una solució de $10 \mu \mathrm{g} / \mathrm{mL}$ de Hoechst (Fluka, Madrid, Espanya) per tal de marcar els nuclis cellulars.

TAULA 6. CARACTERÍSTIQUES DELS ANTICOSSOS SECUNDARIS EMPRATS
EN L'EXPERIMENT. ES CONCRETA L'HOSTE, SI HA ESTAT PURIFICAT,
LA DILUCIÓ UTILITZADA, EL FLUOROCROM I LA CASA COMERCIAL.

Un cop transcorreguda l'hora sencera, es van rentar les mostres amb PBS dues vegades, durant 5 minuts cada rentat. Seguidament, es van treure els cobreobjectes del pou amb unes pinces i es van collocar sobre diferents portaobjectes juntament amb medi de muntatge Prolong Gold ${ }^{\circledR}$ (Thermo Scientific, Rockford).

Les mostres es van deixar assecar a temperatura ambient, amb esferes dessecants i protegides de la llum.

\subsection{Obtenció d'imatges}

Les imatges d'immunofluorescència van ser obtingudes amb un microscopi òptic de fluorescència (BX41, Olympus) utilitzant el software CellB (Olympus) i guardades en format TIF. En cada condició experimental, les imatges van ser adquirides utilitzant els mateixos ajustos de làser i software. El temps d'exposició va ser adaptat a cada marcatge i les imatges del respectiu control van ser obtingudes al mateix temps d'exposició. L'anàlisi i el tractament de les imatges es van dur a terme amb el programa Image J (National Institute of Health, EUA). Algunes imatges van ser modificades amb contrast i brillantor per tal de millorar-ne la visualització; en aquests casos, els seus respectius controls van ser tractats de la mateixa manera.

\section{Resultats i discussió}

\subsection{Presència de mannosa als CA d'LCR}

Per determinar la presència de mannosa als CA de l'LCR, es van realitzar estudis de marcatge amb ConA dels CA d'LCR. Es van analitzar mostres dels 7 casos d'estudi, d'edats compreses entre els 64 i 
83 anys. En els 7 casos estudiats hem observat que hi ha CA i que aquests presenten marcatge, com mostren les imatges representatives de la figura 6.
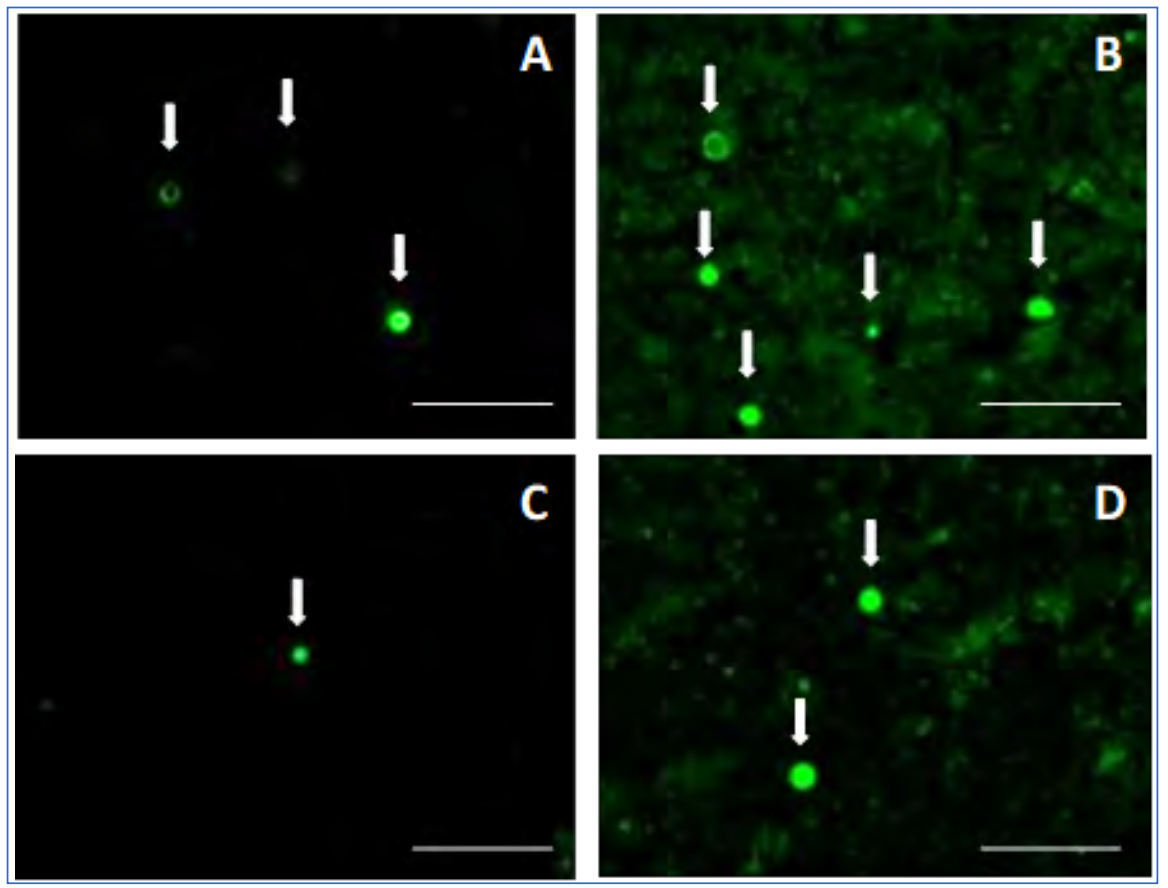

Figura 6. Imatges de mostres d'LCR dels casos d'estudi 4, 5, 6 i 7 (A-D, respectivament), obtingudes per microscòpia de fluorescència, que mostren la presència de CA marcats amb ConA (fletxes) en l'LCR. Barra d'escala: $100 \mu \mathrm{m}$.

El fet que a les imatges B i D s'observi un fons amb fluorescència més intensa no fa referència en cap cas a un marcatge més intens dels CA, sinó que podria ser que la mostra contingués altres restes tissulars que provoquessin un soroll de fons superior al de les altres mostres.

Com ja havia estat publicat en estudis previs (Sarma i Ward, 2011, pp. 227-235; Pirici i Margaritescu, 2014, pp. 33-57), aquesta lectina s'uneix a la mannosa, la qual provocaria posteriorment l'activació del sistema del complement per la via de l'MBL (o via de la lectina) o bé podria induir fagocitosi mitjançada per ManR.

Per tant, aquests resultats suggereixen que els CA tenen mannosa, però, com que la ConA detecta també altres hexoses, encara que amb menor afinitat, no es pot descartar que el marcatge sigui degut a la interacció de la ConA amb altres hexoses, com, per exemple, la glucosa.

\subsection{Presència d'MBL als CA d'LCR}

Un cop es va suggerir amb el marcatge amb ConA la presència de mannosa als CA, com que l'LCR conté MBL, es pot hipotetitzar que els CA de l'LCR ja presenten MBL recobrint-los. Per tal de verificar-ho, es va procedir a fer un estudi d'immunofluorescència amb l'anticòs primari $\alpha$ MBL conjugat amb el fluorocrom FITC en la resuspensió del sediment d'LCR seguint el protocol detallat al punt 2.3. A continuació es mostren imatges representatives obtingudes dels diversos casos estudiats. 
Edusfarm 13 (2021), 73-88

ISSN: $1886-6271$
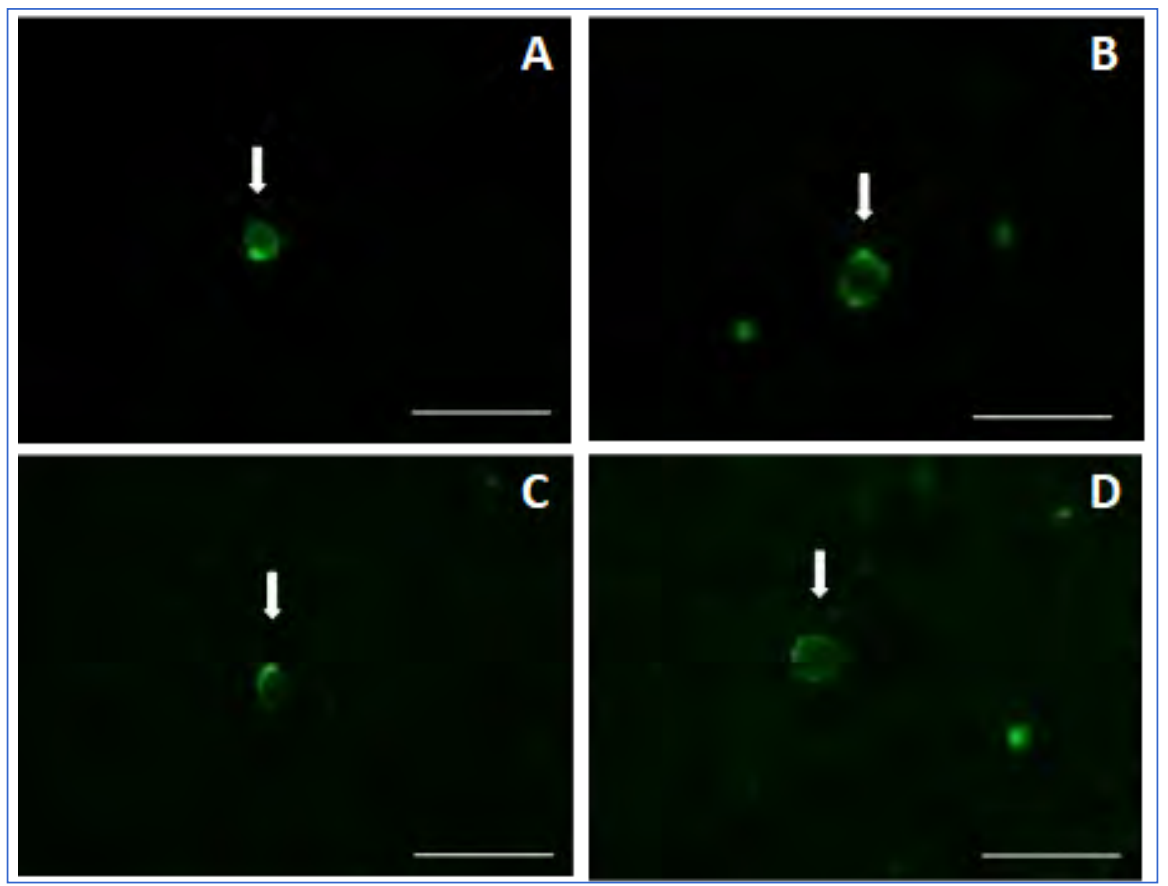

Figura 7. Imatges representatives de mostres d'LCR dels casos d'estudi 1 (A i B) i 3 (C i D), obtingudes per microscòpia de fluorescència que mostren el marcatge dels $\mathrm{CA}$ amb $\alpha$ MBL-FITC (fletxes). Barra d'escala: $50 \mu \mathrm{m}$.

Les imatges mostren el marcatge dels CA amb $\alpha$ MBL-FITC, fet que indica la presència d'MBL recobrint els CA d'LCR.

A més a més, la unió de l'MBL als CA reforça la idea de la presència de mannosa als CA, tot i que alguns estudis indiquen que l'MBL, a part d'unir-se a la mannosa, també s'uneix a altres hexoses, i llavors no es pot descartar que aquesta lectina s'uneixi a altres sucres presents als CA.

\subsection{Presència de C3b als CA d'LCR}

Considerant la presència d'MBL en els CA, i sabent que l'MBL pot activar la via del complement, també es va procedir a fer un estudi d'immunofluorescència en la resuspensió del sediment d'LCR amb l'anticòs primari $\alpha \mathrm{C} 3 \mathrm{~b}$ dels casos 2, 3 i 7 seguint el protocol detallat al punt 2.4.

A continuació, es mostren les imatges representatives obtingudes pels diversos casos estudiats. 

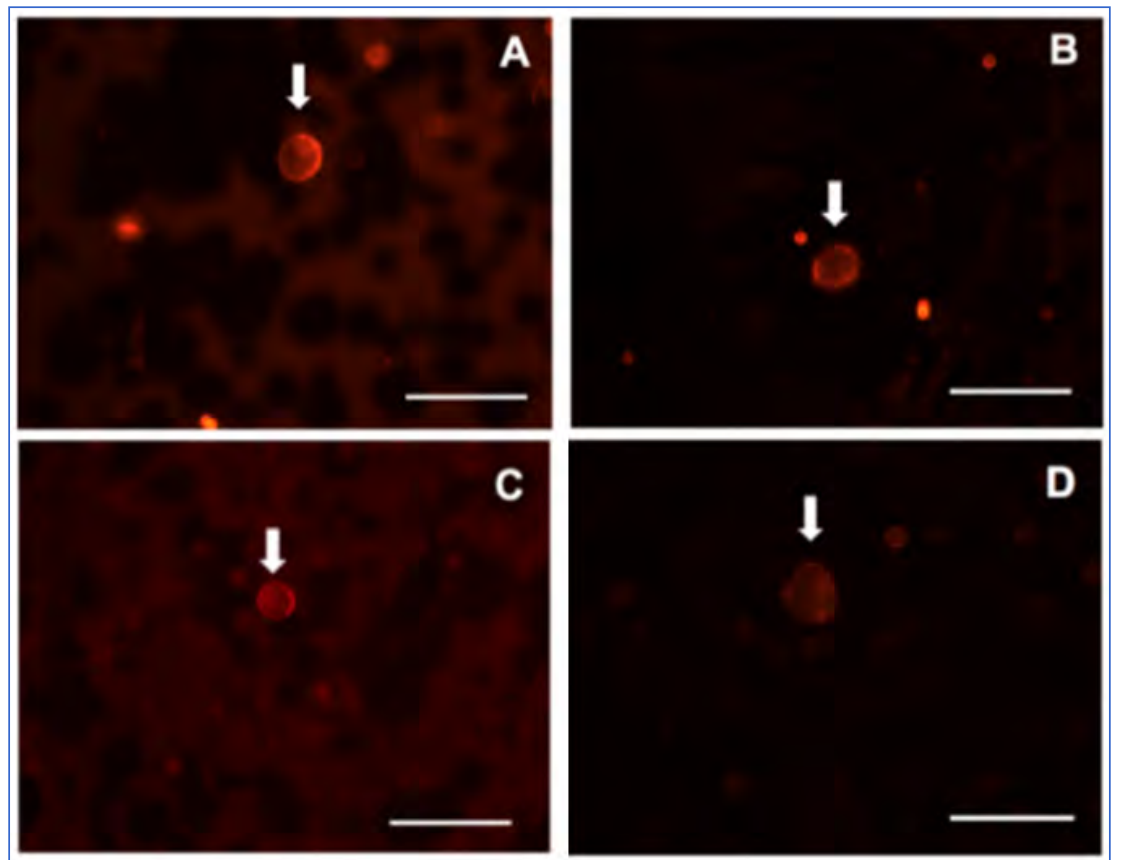

Figura 8. Imatges representatives de mostres d'LCR dels casos d'estudi 3 (A i B), 2 (C) i 7

(D), obtingudes per microscòpia de fluorescència que mostren la presència de C3b en els CA (fletxes) d'LCR mitjançant el marcatge amb l'anticòs $\alpha C 3 b$ (vermell). Barra d'escala: $50 \mu \mathrm{m}$.

El marcatge dels CA amb l'anticòs $\alpha$ C3b confirma que els CA de l'LCR estan opsonitzats amb C3b.

L'opsonització podria ser causada per la prèvia unió de l'MBL, fenomen que desencadenaria l'activació del sistema del complement per la via de la lectina, o podria produir-se directament per l'escissió de C3 per la via alternativa. En l'LCR, la unió de C3b a la superfície dels CA no podria ser derivada de l'activació del sistema del complement mitjançant la via clàssica (per unió de les IgMs), ja que aquestes no són presents a l'LCR.

\subsection{Presència de ManR en macròfags THP-1'}

Un cop suggerida la presència de mannosa en els CA mitjançant el marcatge dels cossos amb ConA i $\alpha$ MBL-FITC, es van portar a terme estudis d'immunofluorescència en macròfags, seguint el protocol detallat al punt 2.5., que permetessin determinar-hi la presència de ManR.

A continuació, es mostren les imatges representatives obtingudes pels diversos casos estudiats.

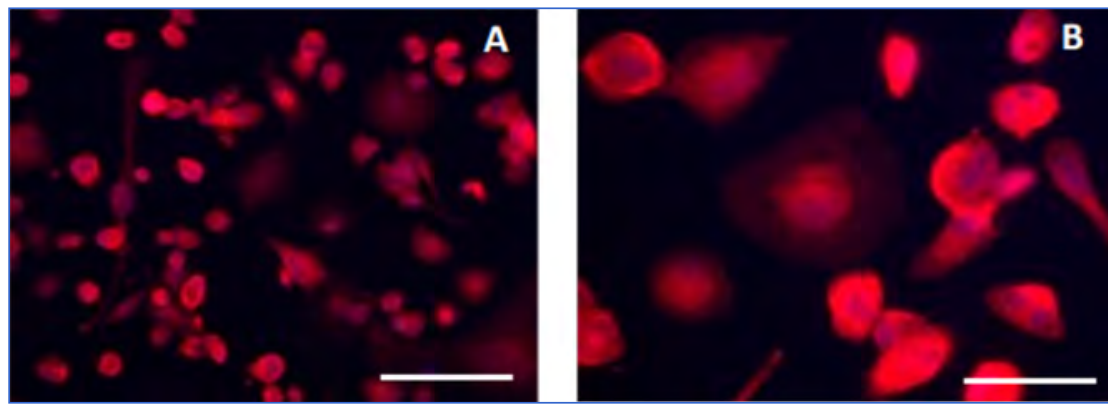

Figura 9. Imatges representatives de mostres de cultius de macròfags, obtingudes per microscòpia de fluorescència, que mostren la presència de ManR, en color vermell, en la superfície dels macròfags. El marcatge en blau correspon al reactiu de Hoechst que marca els nuclis dels macròfags. Barra d'escala: $100 \mu \mathrm{m}$ (A) i $50 \mu \mathrm{m}$ (B). 
Edusfarm 13 (2021), 73-88

ISSN: $1886-6271$

Les imatges mostren un marcatge positiu pel que fa al receptor ManR, el qual permet indicar que els macròfags serien capaços de fagocitar els CA degut al fet que aquests podrien contenir mannosa.

\subsection{Presència de C3bR em macròfags THP-1'}

Un cop es va confirmar el marcatge de C3b en els CA d'LCR, es van dur a terme estudis d'immunofluorescència en macròfags, seguint el protocol detallat al punt 2.5., que permetessin determinar-hi la presència de $\mathrm{C} 3 \mathrm{bR}$.

A continuació, es mostren les imatges representatives obtingudes pels diversos casos estudiats.

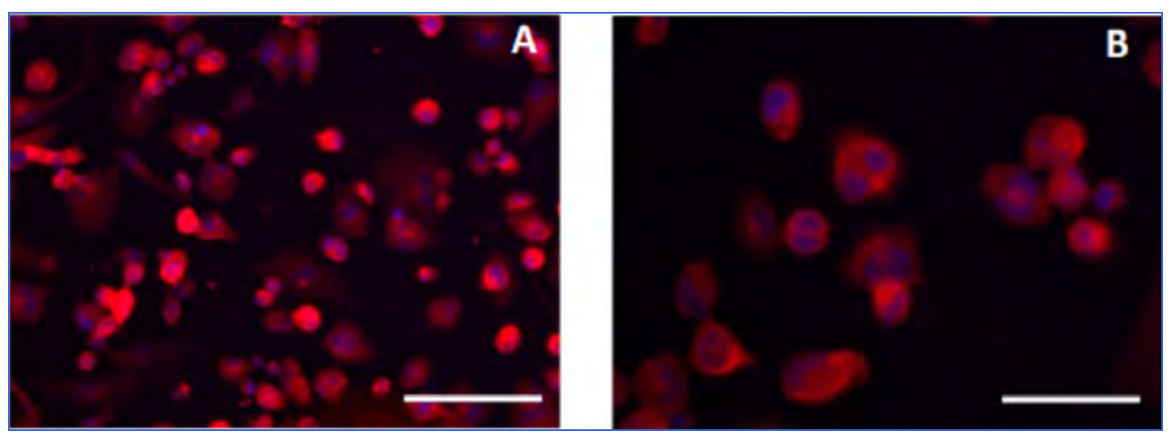

Figura 10. Imatges representatives de mostres de cultius de macròfags, obtingudes per microscòpia de fluorescència, que mostren la presència d' $\alpha \mathrm{C} 3 \mathrm{bR}$, en color vermell, en la superfície dels macròfags. El marcatge en blau correspon al reactiu Hoechst que marca els nuclis dels macròfags. Barra d'escala: $100 \mu \mathrm{m}$ (A) i $50 \mu \mathrm{m}$ (B).

Les imatges mostren un marcatge positiu pel que fa al C3bR, el qual permet indicar que els macròfags serien capaços de fagocitar els CA que han estat opsonitzats pel component C3b del sistema del complement.

\section{Conclusions}

Del present treball se n'extreuen les següents conclusions:

- Els CA d'LCR estan recoberts per la proteïna MBL.

- Els CA d'LCR estan opsonitzats amb C3b.

- Els THP-1' tenen C3bR en la seva superfície.

- La fagocitosi dels CA d'LCR per part de THP-1' podria ser desencadenada per l'activació del sistema del complement i l'opsonització dels CA amb C3b.

- Els THP-1' tenen ManR en la seva superfície.

- No es pot descartar que els CA d'LCR continguin mannosa i que la fagocitosi es produeixi per la presència de ManR a la superfície dels macròfags.

\section{Bibliografia}

AuGÉ, E. et al. (2017) «New perspectives on corpora amylacea in the human brain». Sci Rep, 7, p. 41807.

AUGÉ, E. et al. (2018) «Exploring the elusive composition of corpora amylacea of human brain». Sci Rep, 8(1), p. 13525. 
BARnum, S. (1995) «Complement biosynthesis in the central nervous system». Crit Rev Oral Biol Med, 6(2), pp. 132-146.

CAVAnagh, J. (1999) «Corpora amylacea and the family of polyglucosan diseases». Brain Res Brain Res Rev, 29(2-3), pp. 265-295.

Comas-Herrera, A. et al. (2007) «Cognitive impairment in older people: Future demand for long-term care services and the associated costs». Int J Geriatr Psychiatry, 22(10), pp. 1037-1045.

Coutinho, A., Kazatchine, M. D. i Avrameas, S. (1995) «Natural autoantibodies». Curr Opin Immunol, 7(6), pp. 812-818.

Goldin, A. et al. (2006) «Advanded glycation end products: sparking the developement of diabetic vascular injury». Circulation, 114, pp. 597-605.

KoIVISTo, K. et al. (1995) «Prevalence of age-associated memoryimpairment in a randomly selected population from eastern Finland». Neurology, 45(4), pp. 741-747.

LANZREIN, A., JoBST, K. i Sim, E. (1998) «Mannan-binding lectin in human serum, cerebrospinal fluid and brain tissue and its role in Alzheimer's disease». NeuroReport, 9(7), pp. 1491-1495.

LóPEZ-OTíN, C. et al. (2013) «The hallmarks of aging». Cell, 153(6), pp. 1194-1217.

LuTZ, H. U., BINDER, C. J. i KACERI, S. (2009) «Naturally occurring autoantibodies in homeostasis and disease». Trends Immunol, 30(1), pp. 43-51.

MARTínEZ, V. et al. (2013) «Establishment of an in vitro photoassay using THP-1 cells and IL-8 to discriminate photoirritants from photoallergens». Toxicol In Vitro, 27(6), pp. 1920-1927.

PiRICI, D. i MARgARITESCU, C. (2014) «Corpora amylacea in aging brain and age-related brain disorders». J Aging Gerontol, 2, pp. 33-57.

Purkinje, J. E. (1839) «Bericht über die versammlung deutscher naturforscher und aerzte in Prague» Anat. Physiol Ver, 3, pp. 177-180.

RiBA, M. et al. (2019) «Corpora amylacea act as containers that remove waste products from the brain». Proc Natl Acad Sci USA, 116(51), pp. 26038-26048.

SAKAI, M. et al. (1969) «Studies of Corpora Amylacea: I. Isolation and Preliminary Characterization by Chemical and Histochemical Techniques». Arch Neurol, 21(5), pp. 526-544.

SARMA, V. i WARD, P. (2011) «The complement system». Cell Tissue Res, 343(1), pp. 227-235.

SBARBAt, A. et al. (1996) «Extrusion of corpora amylacea from the marginal gila at the vestibular root entry zone». J Neuropathol Exp Neurol, 55(2), pp. 196-201.

Sibille, E. (2013) «Molecular aging of the brain, neuroplasticity, and vulnerability to depression and other brain-related disorders». Dialogues Clin Neurosci, 15(1), pp. 53-65.

VARKI, A. et al. (2017) Essentials of Glycobiology. Nova York: Cold Spring Harbor Laboratory Press. 